\title{
Electrical Resistivity Tomography Techniques for Identifying Groundwater Pollution Due To Leachate flows at Putri Cempo Landfill
}

\author{
Harjito $^{1 *}$, Suntoro ${ }^{1}$, Totok Gunawan ${ }^{2}$, M. Maskuri ${ }^{1}$ \\ ${ }^{1}$ Department of Environmental Science, Sebelas Maret University, J1. Ir. Sutami No.36A, Jebres, Surakarta, Jawa Tengah 57126, Indonesia \\ ${ }^{2}$ Department of Geography, Gadjah Mada University, Bulaksumur, Caturtunggal, Depok, Sleman, Yogyakarta 55281, Indonesia \\ *Email: jitoo_2007@yahoo.co.id
}

\begin{abstract}
Harjito, Suntoro, Gunawan T, Maskuri M. 2017. Electrical Resistivity Tomography Techniques for Identifying Groundwater Pollution Due To Leachate flows at Putri Cempo Landfill. Proc Internat Conf Sci Engin 1: 103-109. Landfill developed with open dumping system and below the adequate standard potentially lead to new problems like those found at Putri Cempo Landfill in Surakarta City. They include leachate, which easily flows in runoff, seeps through soil and land surface, and infiltrate into groundwater that supplies the surrounding residential wells. A research on leachate spread pattern from landfills to their surrounding areas thereby becomes necessary particularly in terms of environmental pollution potential from underground, which is latent and difficult to monitor. The aims of this research were (1) to identify the areas that experienced groundwater pollution due to leachate flows, (2) to identify the distribution of resistivity in these areas, and (3) to develop a model for leachate management. This research used Electrical Resistivity Tomography (ERT) survey for identifying the distribution of resistivity in polluted areas. It also used groundwater quality analysis for validating the interpretation of the ERT survey results. The results of the research showed that there was an anomaly in the subsurface layer. Materials with resistivity values of $0.25-1.20 \mathrm{ohmm}$ were found in various depths within $0-8 \mathrm{~m}$ below the surface. These values were much lower than the resistivity of the main materials found at the measurement site, i.e. $4.9-13.1 \mathrm{ohmm}$. Accordingly, this anomaly signified the existing influence of pollution. The pollution along the geoelectrical sounding line had uneven distribution and centric pattern at several points that indicated the accumulation sites of leachate. The proposed leachate management model included the constructions of base lining (liner), leachate collection channel, geomembrane-composed final cap, and leachate treatment.
\end{abstract}

Keywords: Putri Cempo Landfill, Groundwater, Leachate, Resistivity

\section{INTRODUCTION}

Landfills contain a variable quantity of toxic materials and comprise a risk for human beings and their environment (Bernard et al., 1997; Ben Salem et al., 2014a, 2014b). One factor that has been a problem at landfills is the presence of leachate especially its alarming mobility within soil and aquifer layers. The most likely emerging environmental problem is caused by leachate migration from landfills to soil layers and groundwater. Leachate is a liquid waste produced by water flowing from external sources into the piles of waste, which then rinses and dissolves the materials inside them. Therefore, it is composed of various organic and inorganic pollutants. When rainwater comes into direct contact with waste, part of it becomes runoff and experiences evapotranspiration. The remaining water infiltrates into a pile of wastes. Leachate occurs when the capacity of waste materials to retain water (field capacity) is exceeded. It is a liquid material composed of a high concentration of organic contents and formed by rainwater flowing on to landfills. Aside from the high organic contents, the environmentally harmful nature of leachate is also caused by the presence of metallic substances (e.g., $\left.\mathrm{Cr}^{+6}\right)$. A poor treatment results in the infiltration of leachate into soil layers, which is followed by groundwater pollution in the surrounding areas. Leachate likely creates problems because it flows both laterally and vertically depending on the characteristics of its surrounding materials. The quantity (discharge) and the quality of leachate are highly fluctuating as they are determined by rainfall and the character of waste materials. The relationship between the amount of rainwater and leachate discharge has to be determined prior to designing the pollutant load and the capacity of a leachate treatment facility. Nowadays, geophysical methods are well-established techniques for approaching and successfully solving hydrogeological, geological, archaeological, and environmental problems (Dahlin and Owen 1998; Atzemoglou etal. 2003).Geo-electrical methods are widely employed in the shallow investigations. Among these, electrical resistivity is the one commonly used to solve various problems (Bernstone etal. 2000). The method is based on the apparent resistivity measurements along the earth surface. Recent developments in the data acquisition have laid to multielectrode resistivity equipment and interpretation of the data in the form of electrical resistivity tomography (ERT) laterally and vertically.This technique has various applications in the landslide studies (Lapenna et al. 2003; Perrone et al. 2004;Drahor et al. 2006), groundwater exploration (Dahlin and Owen 1998; Suzuki and Higashi 2001; Hamzah et al. 2006),and investigation of the waste disposal areas (Bavusi et al.2006; Soupios et al. 2007; Zaidi and Kassem 2012). 


\section{MATERIALS AND METHODS}

\section{Study Area}

Putri Cempo landfill, located in Surakarta city, cover 17 ha surface and was in operated since 1986. Garbage volume increased significantly from year to year, the average garbage supply of 260-290 tons per day. The site is located in the local bedrock in the form of very fine grained sedimentary rocks, igneous rocks, metamorphic rocks that which is unporous (Surono et al, 1992)

\section{Geophysical Survay}

The Electrical Resistivity Tomography (ERT) method in this research applied Schlumberger electrode array to obtain primary data from direct measurement at the field. It firstly determined five measuring points, which were located on the north, west, east, and at the center of the landfill. These measuring points provided information on areas with the greatest and smallest pollutant anomaly by interpreting the differences between the electrical resistivity levels acquired from geo-electrical sounding and those of clean water, i.e. between $10-100 \mathrm{ohm}-\mathrm{m}$. These values were the base for determining which points had the greatest and the smallest anomaly and for identifying the direction of leachate flows. The equipment used in this research was GPS Garmin Vista, compass, roll-up tape measure, and ERT Geoelectrical Instrument. ERT assesses the layers of the underground materials based on the nature of their resistivity (Telford et al., 2004). Electrical resistivity $(\rho)$ is controlled by electrical current (I) and electrical potential difference $(\mathrm{V})$, which are both obtained from direct measurement at the field (Alfred et al., 2008). They are acquired by injecting electrical current underground using pairs of current electrodes $(\mathrm{C} 1, \mathrm{C} 2)$ and potential electrodes (P1, P2) (Loke, 2000).

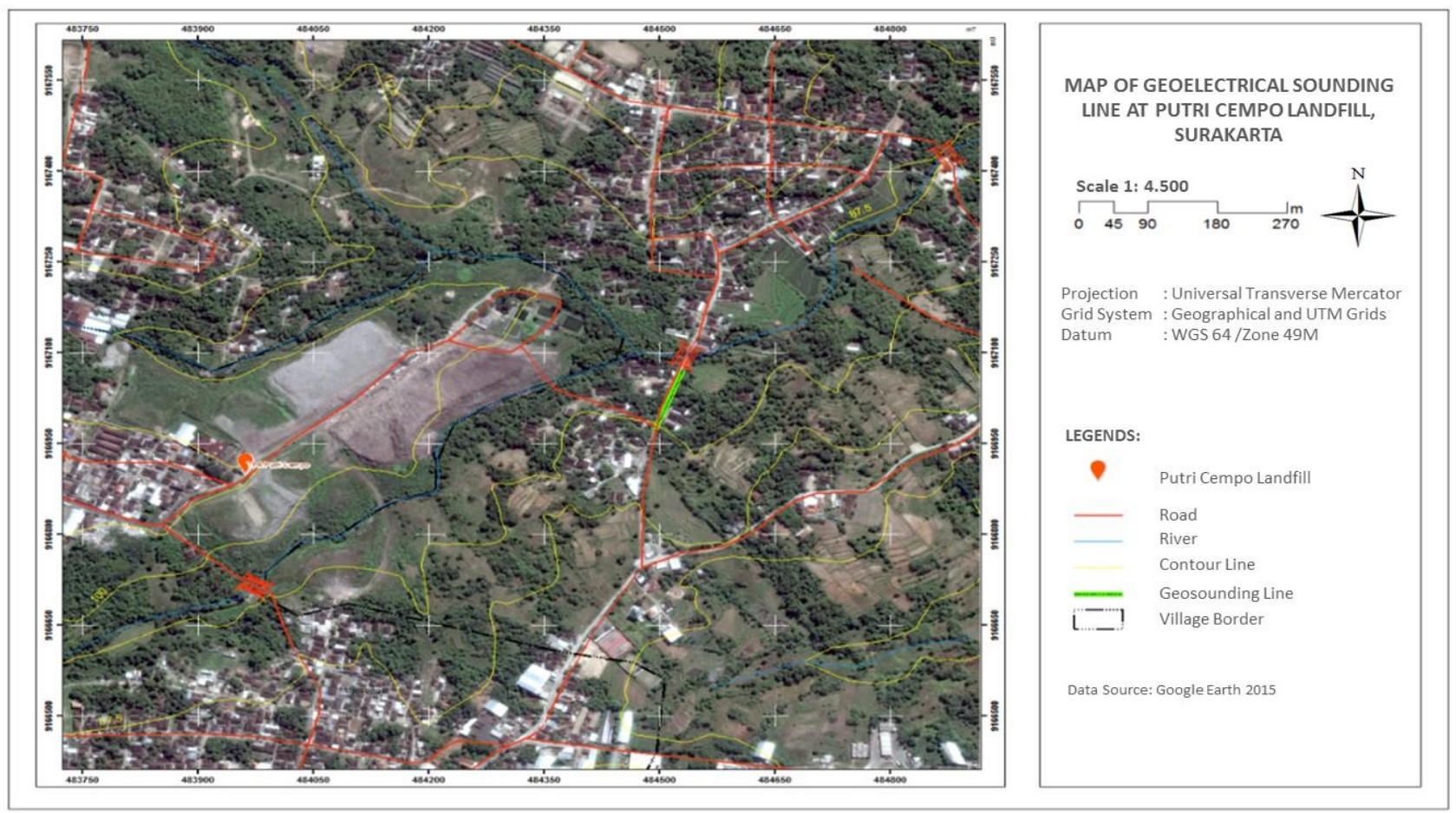

Figure 1. The location of geoelectrical sounding.

\section{Data Acquisition}

Electrical current was injected through a set of electrodes arranged in Sclumberger configuration (Figure 2). Electrical current flowed through a circuit, as illustrated in Figure 2. Current electrode pairs $(\mathrm{C} 1, \mathrm{C} 2)$ were placed in a wider distance than potential electrode pairs $(\mathrm{P} 1, \mathrm{P} 2)$. The distance $(\mathrm{AB}$ or $\mathrm{L})$ was wider in order to measure the electrical resistivity of deeper materials. When electrical potential difference becomes difficult to measure, the sensitivity of the measuring instrument decreases; hence, the distance between potential electrode pairs (MN or a) has to be widened. The electrical current and electrical potential difference for every distance formed between current and potential electrodes were observed in order to calculate the pseudo-electrical resistivity of the composing materials in the research area. Data acquisition was conducted at five measuring points throughout Putri Cempo Landfill. These points were distributed evenly in all underlying geological formations in the research area. 


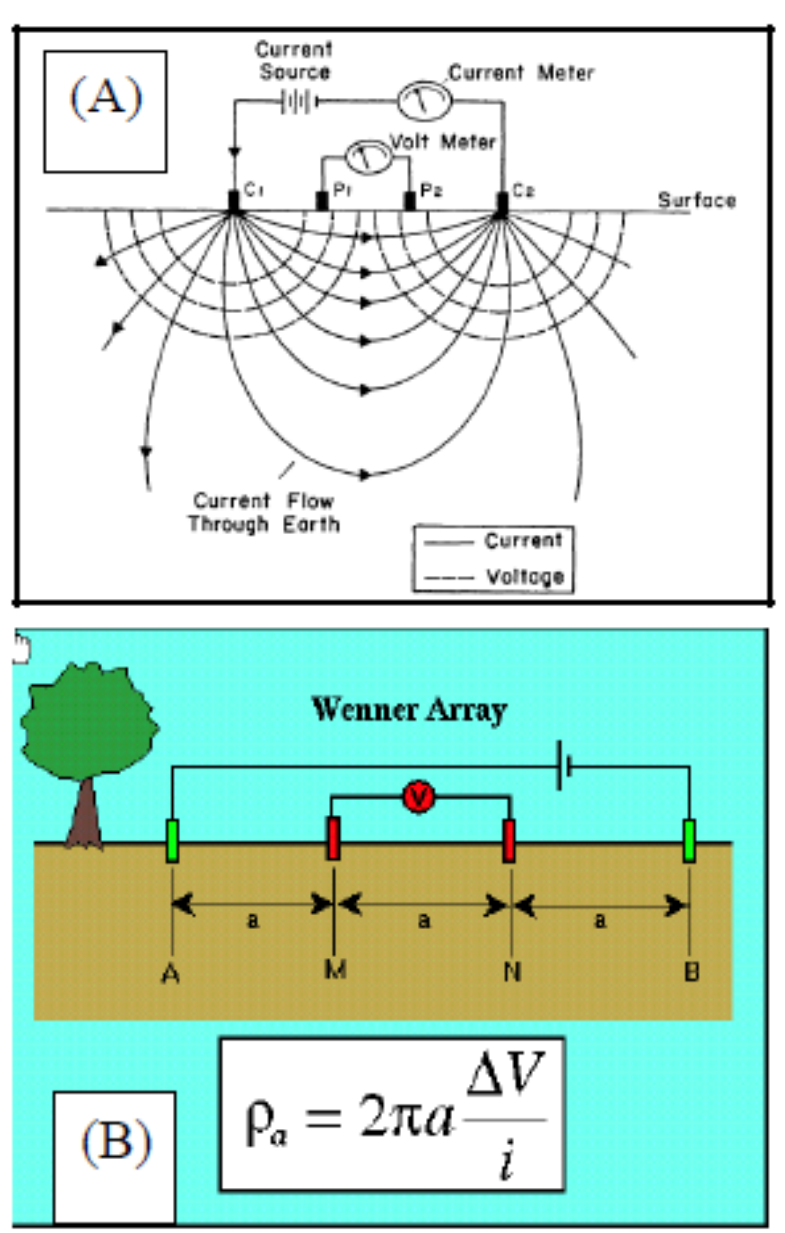

Figure 2. The arrangement of electrodes in Schlumberger configuration forms an electrical circuit.

\section{Data Processing}

Data acquisition process produces electrical current (I) and electrical potential difference (V). However, data processing requires pseudo-electrical resistivity instead of these two data. The pseudo-electrical resistivity ( $\rho a)$ was calculated based on electrical current and electrical potential difference using the following equations:

$$
\begin{aligned}
& \mathrm{R}=\frac{\mathrm{V}}{\mathrm{I}}, \\
& \rho \mathrm{a}=\frac{\mathrm{V}}{\mathrm{I}} \cdot \mathrm{k}, \\
& \rho \mathrm{a}=\mathrm{R} \cdot \mathrm{k} .
\end{aligned}
$$

In inverse modeling technique, the inversion process of pseudo-electrical resistivity was conducted using IP2Win computer program. This process aimed to convert pseudo-electrical resistivity into the actual electrical resistivity of the materials.

\section{Data Analysis Technique}

In order to identify the location of leachate accumulation, this research used quantitative descriptive analysis, i.e. an analysis technique for understanding the distribution of electrical resistivity in polluted areas. Every material has its own range of electrical resistivity. A lower electrical resistivity than the inherent range of related materials indicates the presence of leachate. For example, a groundwater aquifer (freshwater) with electrical resistivity between $10-100 \Omega$ m will present a reading of lower than $10 \Omega \mathrm{m}$ if it is polluted. Identifying the spread direction of leachate in the research area was based on the electrical resistivity pseudo-section and three-dimensional model that were correlated with hydrologic and geologic data. The pseudo-section provided information on both lateral and vertical distribution of electrical resistivity as well as depth. The distribution was presented in a log data model in order to create a three-dimensional model for either electrical resistivity or composing material/ lithology. The three-dimensional model that had been correlated with hydrologic and geologic data provided information on the spread direction of the leachate. In addition, laboratory analysis on groundwater quality aimed to validate the ERT survey result, which waspart of quantitative descriptive analysis, with the Regulation of the Ministry of Health No. 492/MenKes/Per/IV/2010 on the Requisite of Drinking Water Quality as reference.

\section{RESULTS AND DISCUSSION}

Groundwater flow is a media that has a continuous influence on the surrounding underground environment. Poor and polluted water quality affects the environment negatively. Leachate that fuses into groundwater flows from one place to another in order to erase the energy difference between leachate and groundwater. It is found at the bottom of landfill. When it seeps through the underlying soil layers, many chemical and biological elements that initially present in it will be released into the surrounding soil layers through filtration and absorption whose rates depend on the characteristics of the soil. In order to identify areas that experience leachate-contaminated groundwater, this research used Electrical Resistivity Tomography (ERT). The geoelectrical sounding analysis in Putri Cempo Landfill, Surakarta City produced different patterns that were classified into four resistivity groups. This range is, then, classified based on the categories proposed by Lowrie (2007) and Milsom (2003). The first group was found at a depth of $0-1.83 \mathrm{~m}$ and distributed evenly with diverse resistivity values, i.e. between 2-255 ohmm. These layers were inferred to be surface soils that comprised materials from clay to sand, which formed a widely diverse range of resistivity. These soils are formed due to human activities that supply additional or new materials from different places for various purposes like construction and agriculture.

The second group had a resistivity of 4.9-13.1 ohmm, which was distributed at a depth of 2-10 m. As shown by the resistivity values, this layer was interpreted as clay layering with different levels of saturation. The higher the resistivity, the lower the water content in clay layers; and vice versa. The clay layer at this zone is controlled by the activities of Bengawan 
Solo River, located on the south of the zone, that supply the main clay materials.

The layering of clay materials, down to $10 \mathrm{~m}$ from the surface, forms a groundwater zone composed of clays. According to Purnama (2010), the groundwater system formed by this type of materials can be defined as aquiclude or aquitard. This system stores water but restricts it from flowing to other areas, which then traps fluids inside the clays for a long time.

The third layer had a resistivity of 35.2-94.9 ohmm, which was distributed at a depth of more than $10 \mathrm{~m}$. It was interpreted as a mixed layering of clay and sand produced from the activities of Merbabu, Merapi, and Lawu Volcanoes in the past. This sandy clay layer is a transition between the clay-composed layer formed by Bengawan Solo River and the sand-composed one formed by past volcanic activities. The presence of sand and clay composition increases permeability and porosity (Todd, 1980) and, thereby, improves the capacity to absorb, store, and channel water.

The fourth layer had a resistivity of $0.25-1.20 \mathrm{ohmm}$ at various depths within $0-8 \mathrm{~m}$ from the surface. It presented an anomaly because its resistivity was much lower than that of the main materials found at this depth, i.e. 4.9-13.1 ohmm. Such anomaly was caused by leachate accumulation from the landfill. Leachate is a liquid material produced from organic waste decomposition that potentially increases the ionic contents of soil and groundwater. The addition of leachate into the groundwater system increases the electrical conductivity of contaminated materials/groundwater steeply, which leads to a significant decline in electrical resistivity. Therefore, this anomaly was identified as the indications of pollution. It was validated by the results of laboratory analysis, which showed that one of the chemical elements, i.e. Nitrate, exceeded the standard set in the Regulation of the Ministry of Health No. 492/MenKes/Per/IV/2010 on the Requisite of Drinking Water Quality. The pollution spread unevenly along the geoelectrical sounding line and with a centric pattern at several points, representing the accumulation sites of leachate. The distribution of resistivity and its interpretation is visualized in Figure 3.

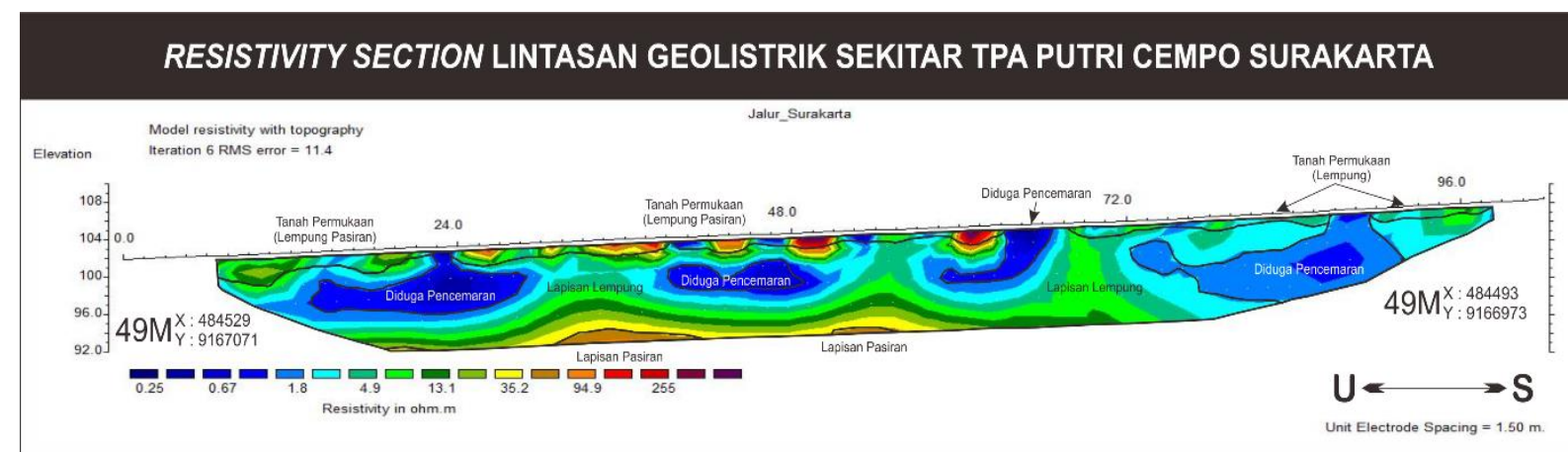

\section{INTEPRETASI RESISTIVITY SECTION LINTASAN GEOLISTRIK SEKITAR TPA PUTRI CEMPO SURAKARTA}

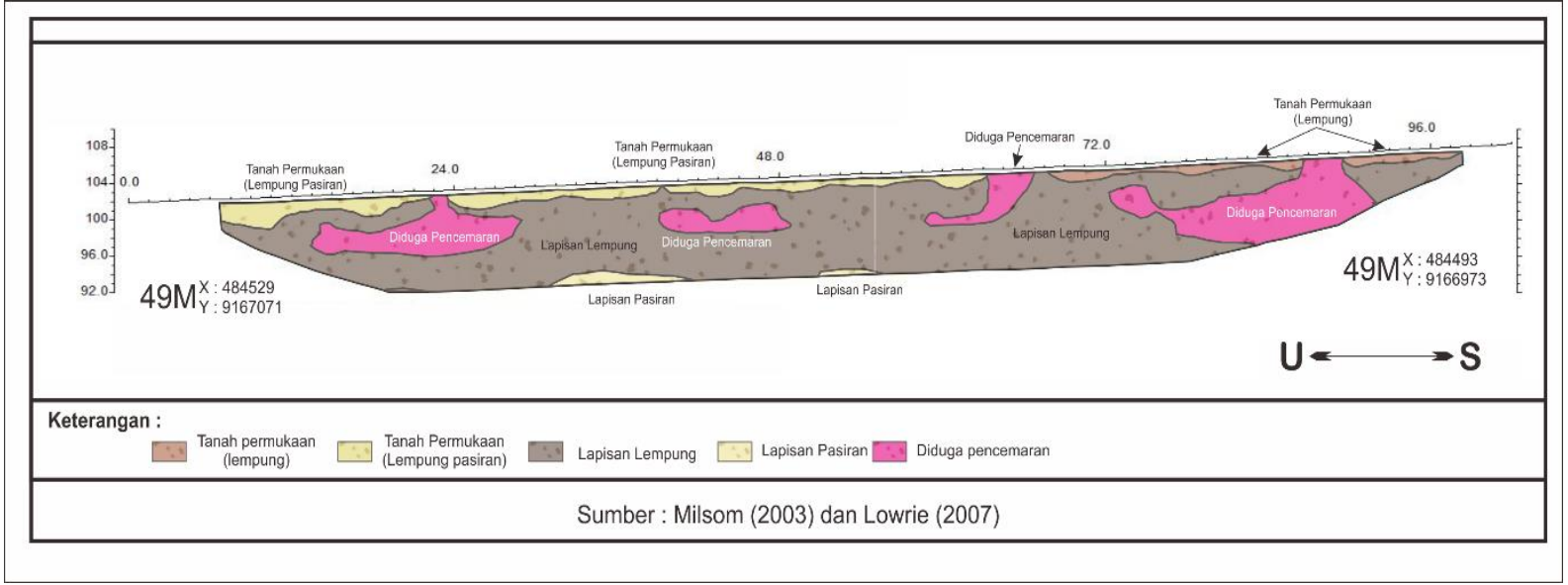

Figure 3. Resistivity section and interpretation result along the sounding line around Putri Cempo Landfill.

The pollution was found at the clay layers, meaning that the pollutants were hardly rinsed and transported to other areas. This entrainment may lead to the accumulation of a larger pollution that negatively affects the environmental quality particularly from groundwater aspect. The groundwater pollution in the surrounding areas of Putri Cempo Landfill is in line with the research conducted by Yudhyarto et al. (2015). This research, 
referring to the information provided by the local people, found that the water in the residential wells was often yellowish and blackish after the construction of Putri Cempo Landfill, indicating the presence of groundwater pollution due to leachate accumulation from the landfill.

The pollution around the landfill accentuates the urgancy of a better management in leachate treatment in order to contain the contamination. The shape and plume of leachate distribution depend on the concentration of pollutant and the type of groundwater flow. Pollutants with high concentration in fast groundwater flow result in a big and extensive plume. The model produced the three-dimensional topography of the research area, which provided a description of the groundwater flow. Based on the three-dimensional model of groundwater conductivity, the obtained shape and plume are presented in Figure 4. Meanwhile, according to the three-dimensional model (Fance model) resulted from the ERT surveys at G1 and G2 with intersecting lines, the spread direction of the leachate was indicated by low electrical resistivity, as presented in Figure 4.

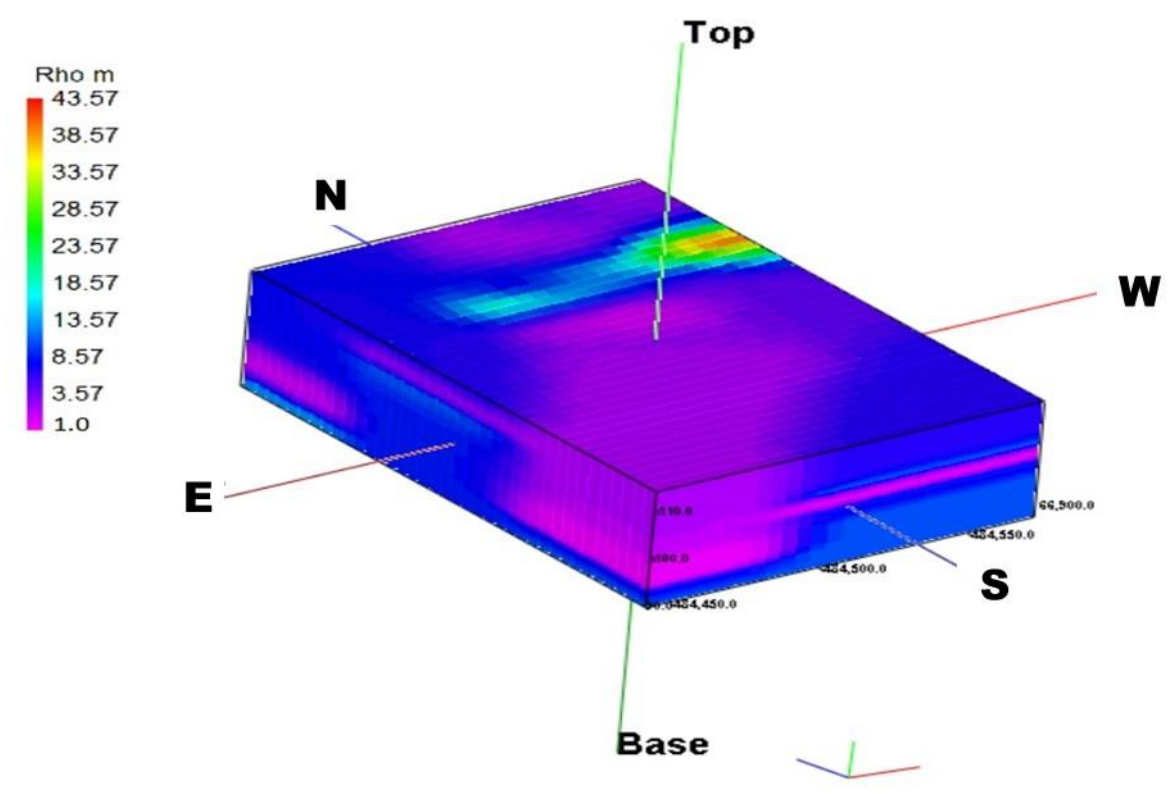

Figure 4. The three-dimensional pattern and spread direction of leachate.

Figure 4 also shows that the leachate, marked in purple $(\mathrm{Rho}=1 \mathrm{ohm} \mathrm{m})$, flows southwestward. This flow pattern is influenced by the minor structure of the lithological layers, composed of sandy materials with medium porosity, and the layering that lies parallel to contour and toward the southwest.

The landfill management model, based on groundwater system vulnerability and its resultant leachate flows, is designed as follows:

\section{Base Lining (Liner)}

Infilling requires a base lining system that aims to reduce the mobility of leachate into groundwater. An effective liner prevents pollutants from migrating to the environment, especially groundwater. However, there is empirically no $100 \%$ efficient liner system. The discharge of leachate is inevitable, which implies the need of leachate collection channel aside from liner system. Therefore, the bottom of landfill has to be sealed with layers of liner materials to prevent leachate from migrating to outside of the landfill and equipped with leachate collection channel. The liner is made of natural materials (e.g., clay, bentonite) or synthetic materials. It may comprise one material (single) or a combination between natural and synthetic materials, commonly referred to as geocomposite, depending on the necessary functions.

The layer formations and the types of liner materials vary according to the characteristics of solid waste piled onto the landfill. Bagchi recommends that applying single liner system composed of clay is sufficient for city waste. The recommended base lining is geosynthetic or known as flexible membrane liner (FML). The commonly used geosynthetic for base lining is Geotextile as filter, Geonet as drainage channel, and Geomembrane and geocomposite as buffer layer. Geomembrane, as an impermeable layer, is a geosynthetic made of impermeable polymer. The best polymer is high-density polyethylene (HDPE) that is resistant to chemical reactions occurring in hazardous materials waste. The scheme of double liner system between FML and compacted soil is presented in Figure 5. 

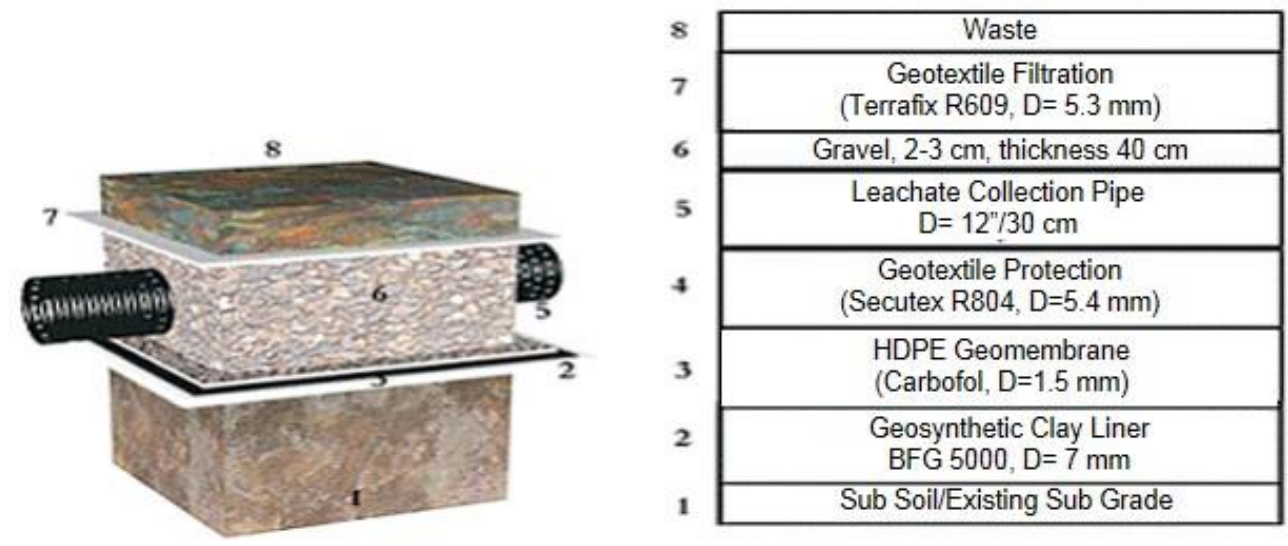

Figure 5. The structure of base lining (liner) system.

\section{Leachate Collection Channel}

Leachate collection system is recommended to have holed pipes located inside the rock-coated channels. In addition, it requires coated channels that contain hollow river stones. The facilities required for pipe-equipped leachate collection channels are generally as follows:

1. Terraced Slope

In order to prevent leachate from accumulating at the bottom of landfill, the base of landfill is transformed into terraces with certain slope (1-5\%) that allows leachate to flow into collection channels $(0.5-1 \%)$. In order to make leachate flow into collection or recirculation unit, every collection channel is equipped with holed pipes. The maximum slope and length of collection channels are designed based on the capacity of collection channel facility. In order to assess this capacity, the research uses Manning's equation.

2. Piped Bottom

The bottom of landfill is divided into several rectangles with clay divides. The width of the divide depends on the width of the cells. Leachate collection pipes are placed parallel to the length of cells and directly on geomembrane.

\section{Final Cap}

The final cap of landfill consists of several parts. The upper part is soil that functions as protection and plantgrowing medium (top soil). When soil in the area does not accord to the requisites, it needs an improvement, i.e. by mixing or replacing it with soils from other areas. The thickness of top soil is $60 \mathrm{~cm}$. The layer beneath it functions as drainage system, which drains as much precipitation as possible so that rainwater does not seep into the layer beneath it. The materials used for composing this layer are porous, e.g., sand, gravels, and synthetic materials like geonet. The thickness of this layer is around $30 \mathrm{~cm}$. The second part is leachateretaining layer, which is commonly composed of geocomposite (geomembrane and compacted clay). The thickness of geomembrane is recommended to be more than $2.5 \mathrm{~mm}$; while the thickness of clay is more than 50 $\mathrm{cm}$. Beneath this layer is the gas ventilation system,

which is a requisite for city waste treatment because most of city waste is organic matters that decompose biologically. In aerobic condition, the resultant gas is mainly carbon dioxide and methane. Therefore, this biogas can be utilized as an alternative source of energy. The layer of gas ventilation system consists of porous medium like sand/gravel or pipe system. The lowest part of the final cap is subgrade layer that functions to increase the stability of the surface of landfill. Furthermore, it helps to form a necessary slope for accelerating lateral drainage and reducing hydraulic level. Its thickness is $30 \mathrm{~cm}$. Aside from this final cap, reducing the amount of overland flow that enters landfill involves slope arrangement, equipped with surface drainage and sowing.

\section{Leachate Treatment}

Leachate contains the same composition as liquid domestic waste, but the concentration of its organic matters is higher than a pile of domestic waste, as indicated by the high $\mathrm{BOD}_{5}$ level of leachate, i.e. around 2,000-30,000. Leachate treatment system is divided into two steps, namely secondary treatment and tertiary treatment. The secondary treatment consists of stabilization pond (facultative and anaerobic) and aeration pond.

\section{CONCLUSIONS}

According to the aforementioned results, the research conclusion is as follows:

1. Data analysis of geo-electrical sounding in the research area shows an anomaly in the electrical resistivity of the subsurface materials. The anomaly comprises a resistivity of $0.25-1.20 \mathrm{ohmm}$ at various depths within $0-8 \mathrm{~m}$ below the surface, which is much lower than the resistivity of the main materials found at this depth, i.e. 4.9-13.1 ohmm. Therefore, this anomaly indicates the presence of pollution.

2. The leachate flow pattern is influenced by the minor structure of the lithological layers, composed of 
sandy materials with medium porosity, and the southwestward, parallel layering to contour.

3. The landfill management model, based on groundwater system vulnerability and the resultant leachate movement, consists of base lining (liner), leachate collection channel, final cap composed of geomembrane, and leachate treatment.

\section{ACKNOWLEDGEMENTS}

The author would like to thank Dr. M. Widyastuti,M.T, Head of The Hidrology and Enviromental Climatology, for his encouragement and constant support. Thanks are also due to Dr. Rika Harini,M.P, Head of the Enviromental Geography Department, and to the author's colleagues Erik Febriarta, S.Si., M.Sc and Ajeng Larasati,S.Si for reading and improving the paper. Thanks also are due to Okta Rama,S.Si and Sambodo,S.Si for their help in the field.

\section{REFERENCES}

Allred, B.J., Daniels, J.J., and Ehsani, M.R. 2000. Handbook of Agricultural Geophysics. BocaRaton: CRC Press.

Atzemoglou A, Tsourlos P, Pavlides S (2003) Investigation of the Tectonic Structure of the NW Part of the Amynteon Basin (NW Greece) by means of a Vertical Electrical Sounding (VES) survey.J Balkan Geophys Soc 4:188-201

Bavusi M, Rizzo E, Lapenna V (2006) Electromagnetic methods to characterize the Savoia di Lucania waste dump (Southern Italy).Environ Geol 51:301-308

Dahlin T, Owen R (1998) Geophysical investigations of alluvial aquifers in Zimbabwe. Proceedings of the IV Meeting of the Environmental and Engineering Geophysical Society. Barcelona,Spain, pp 151-154

Bernard, C., Persoone, G., Janssen, R.C., Le Dû-Delepierre, A., 1997. Estimation of the hazard of landfills through toxicity testing of leachates-2. Comparison of physico-chemical characteristics of landfill leachates with their toxicity determined with a battery of tests. Chemosphere 35, 27832796.

Ben Salem, Z., Capelli, N., Grisey, E., Baurand, P.E., Ayadi, H., Aleya, L., 2014a. First evidence of fish genotoxicity induced by heavymetals fromlandfill leachates: the advantage of using the RAPD-PCR technique. Ecotoxicol. Environ. Saf. 101, 9096.
Ben Salem, Z., Capelli, N., Laffray, X., Grisey, E., Ayadi, H., Aleya, L., 2014b. Seasonal variation of heavymetals in water, sediment and roach tissues in a landfill draining system pond (Etueffont, France). Ecol. Eng. 69, 25-37.

Bernard, C., Persoone, G., Janssen, R.C., Le Dû-Delepierre, A., 1997. Estimation of the hazard of landfills through toxicity testing of leachates-2. Comparison of physico-chemical characteristics of landfill leachates with their toxicity determined with a battery of tests. Chemosphere 35, 27832796.

Drahor MG,Göktürkler G, BergeMA,Kurtulmus TO (2006) Application of electrical resistivity tomography technique for investigation of landslides: a case from Turkey. Environ Geol 50:147-155

Hamzah U, Yaacup R, Samsudin AR, Ayub MS (2006) Electrical imaging of the ground-water aquifer at Banting, Selangor,Malaysia. Environ Geol 49:1156-1162

Lapenna V, Lorenzo P, Perrone A, Piscitelli S, Sdao F, Rizzo E (2003) High-resolution geoelectrical tomographies in the study of the Giarrossa landslide (southern Italy). B Eng Geol Environ 62:259-268Perrone et al. 2004;

Loke, M.H. 2000. Electrical Imaging Survey for Environmental and Engineering Studies. Accessed on March 06, 2009 from http://www. geometrics.com.

Lowrie, W. 2007. Fundamentals of Geophysics. New York: Cambridge University Press.

Milsom, J. 2003. Field Geophysics The Geological Field Guide Series. New York: John Wiley \& Sons Ltd.

Purnama,S.2010. Hidrologi Airtanah. Yogyakarta: Penerbit Kanisius

Soupios P, Papadopoulos I, Kouli M, Georgaki I, Vallianatos F, Kokkinou E (2007) Investigation of waste disposal areas using electrical methods: a case study from Chania, Crete, Greece.Environ Geol 51:1249-1261

Surono, B. Toha dan Sudarno, 1992. Peta Geologi Lembar Surakarta - Giritontro. Pusat Penelitian dan Pengembangan Geologi. Bandung

Telford, W.M., Geldart,L.P., and Sheriff, F.E. 2004. Applied Geophysics. London: Cambridge University Press

Todd, D.K. 1980. Groundwater Hydrology. $2^{\text {nd }}$ Edition. New York: John Wiley \& Sons

Yudhyarto, B., Utomo, B., and Sulastoro. 2015. Pengaruh Tempat Pembuangan Akhir Sampah Putri Cempo Surakarta Terhadap Kualitas Air Tanah Dangkal Penduduk Sekitar. e-Jurnal MATRIKS TEKNIK SIPIL Juni 2015. Hal 564-569.

Zaidi FK, Kassem OMK (2012) Use of electrical resistivity tomography in delineating zones of groundwater potential in aridregions:a case study from Diriyah region of Saudi Arabia. Arab J Geosci 5:327-333. doi: 10.1007/s12517-010-0165-7

Suzuki K, Higashi S (2001) Groundwater flow after heavy rain in landslide-slope area from 2D inversion of resistivity monitoring data. Geophysics 66:733-743 
THIS PAGE INTENTIONALLY LEFT BLANK 